MedieKultur | Journal of media and communication research | ISSN 1901-9726

Article - Open section

\title{
Organizing for the auteur: a dual case study of debut filmmaking
}

\section{Sara Malou Strandvad}

MedieKultur 2012, 53, 118-135

Published by SMID | Society of Media researchers In Denmark | www.smid.dk The online version of this text can be found open access at www.mediekultur.dk

In this article, the question of the auteur is transferred from film criticism to filmmaking processes in order to analyze how production practices are organized. By doing so, the article shifts the focus from understanding the concept of the auteur from a textual perspective to a sociological analysis, where the concept is understood as a social resource that enables and structures certain kinds of interactions. Accordingly, the article investigates how the ideal of the auteur is invoked in a dual case study of the making of two Danish debut films. In both projects, the directors embody the motif of the project and the auteur notion thereby comes to be activated as an organizing device. The analysis shows that putting the auteur notion to use to organize the making of films has various consequences, not all of which are intended and beneficial.

\section{Introduction}

By definition, the concept of the auteur is an aesthetic category that delimits filmmakers of a certain quality. Accordingly, the most important task in auteur studies is to identify who auteurs are, categorizing certain directors as outstanding. The primary parameter used in this categorization is that an auteur must be the author whose style is recognizable from film to film. 
As an alternative to traditional auteur studies, this article suggests using the notion of the auteur to understand work processes of debutante filmmakers. Clearly, this may seem a paradoxical suggestion. Debutantes have not produced any films. Thus, the merits of their work cannot be evaluated and they cannot be auteurs. Yet, exactly this paradox forms the question that this article looks into: if debutantes obviously do not live up to the criteria that define auteurs, then why are they met with expectations that seem to be placed on auteurism?

In two case studies of film projects headed by young Danish directors making their first feature-length films, the article investigates how the notion of the auteur is activated and what consequences such activations have. The proposal of the paper, that the auteur notion works as a guide that has various effects, some of which may be negative, differs from the traditional use of the auteur concept as a superlative to categorize exceptional filmmakers. In so doing, the article suggests that the notion of the auteur not only plays a role in film studies, but comes alive in filmmaking practices too. Hence, the article builds on Bordwell and Thompson's assessment that the notion of director-as-author "remains probably the most widely shared assumption in film studies today" (Bordwell \& Thompson, 1993, p. 38; cited in Gaut, 1997, p. 149), adding that this may not only be the case in film theory but also in practice.

In suggesting that the concept of the auteur has moved from theory to practice, the article follows Corrigan's trajectory (Corrigan, 1991; Andrew, 1993; Martin, 2004). However, whereas Corrigan made the argument that auteurism is "a commercial strategy for organizing audience reception" (ibid., p. 103), this article aims to take up the more general claim that he makes that filmmakers are well aware of auteur theory and use this theory in various ways (see Orgeron, 2007, for an excellent example).

\section{The notion of the auteur}

Although it has since been applied as a theory, auteurism was initially a polemical movement in film criticism in the 1950s and 1960s. One of the early exponents of auteurism was director and film critic François Truffaut, a member of the group involved in the French journal Cahiers du Cinéma, where the concept of the auteur was originally formulated. Truffaut sought to raise the status of films, made by directors with distinct visual styles, to the realm of art. Writing in 1954, Truffaut argued against a tradition that saw filmmaking as adaptation of literary works, a position he found was downplaying the visual side of films. In its place, Truffaut introduced what he termed a "cinéma d'auteurs" that valued cinematic expression as an art form in its own right. This appraisal of the director's job implied that the director came to be seen as the central creative agent in filmmaking.

American film critic Andrew Sarris adopted from Cahiers du Cinéma the idea that the director is the author of a film and began to propagate the concept of the auteur in the early 1960s. Sarris elaborated the inspiration from Cahiers du Cinéma by translating auteurism into an evaluative theory based on three criteria: the director should be technically 
competent, the personality of the director should be distinguishable, and the director's style should be unfettered by industry structures. By an application of these criteria, Sarris constructed a hierarchical system to categorize American auteurs.

These early versions of auteurism share three basic assumptions. Firstly, the auteur is the creator of the film, even though it is produced collectively. Secondly, the personality of the auteur is expressed in the film, in other words it is inscribed in the film so that this personality is recognizable and can be traced across the works of the auteur. Thirdly, auteur films can be distinguished from non-auteur films on the basis of the two first assumptions, which implies a normative judgment in favor of auteur film (Caughie, 1996).

By paraphrasing the Romantic conception of the artist as genius in installing the director as creator of the film, early auteurism came to cement the status of film as an art form. Like Romanticism, early auteurism presupposed the existence of an individual who possesses extraordinary abilities for self-expression (Negus \& Pickering, 2004). Accordingly, the early forms of auteurism are also known as "romantic auteurism" (Wexman, 2003).

Auteurism has been the target of severe critiques; however, it still prevails (e.g., Burke, 1992; Grodal et al., 2005; Livingston, 1997; Lovell \& Sergi, 2005; Sellors, 2007). Critiques of auteurism can roughly be divided into two types: a post-structuralist critique declaring the author to be dead or constructed, a fiction, or an invented subject position. This line of critique suggests transferring authorship from the singular, intentional human agent to receivers or discourses of certain historical periods (Barthes, 1968; Foucault, 1969; Gerstner \& Staiger, 2003). Another type of critique derives from empirical studies that have highlighted the importance of industry structures, producers, and collaborators, which demonstrate the inadequacy of ascribing films solely to their directors (Carringer, 1996, 2002; Schatz, 2004; Spadoni, 1995; Staiger, 1981, 2004; see also Gaut, 1997). Although these two types of critiques differ with regard to their foundation (a theoretically based argument concerning finished works versus an empirically founded approach considering production processes), and how radical a critique they propose, both point to broader, heterogeneous factors to explain the origins of artworks. In this regard, the paper is informed by these two alternatives to auteurism. Yet, both types of critiques are entangled in their relation to the auteurist stance, which makes them confirm the premises of auteurism. Let me elaborate this view.

Although none of the founding fathers of post-structuralism addressed the concept of the auteur, their work on the de-construction of the subject position of the autonomous artist has had a tremendous influence on the auteur debate (Gerstner \& Staiger, 2003). Starting from the famous essays with telling titles, such as, "The Death of the Author" (1968) by Barthes and "What Is an Author?" (1969) by Foucault, an era of post-structuralism was launched that made a break with romantic auteurism by reversing its logic. Basically, the argument in both essays was that the author is produced. An author, rather than being the source of a work, is a subject position that is invented. Accordingly, Foucault used the label author-function to describe the author, while Barthes spoke of the author as being a fiction, an author-fiction. In Barthes' analysis of the author's death, authoring of a text was handed 
over to its receivers. According to Barthes, a work did not have a final meaning, but was open for multiple interpretations, which turned readers into producers and, simultaneously, dissolved the authority of the author (Barthes, 1968). Although Barthes articulated a desire for the author once this figure had been displaced, he did not reintroduce an originating subject. Foucault, in contrast to Barthes, did not declare the author to be dead, but portrayed the author as a historical notion that is upheld because it serves a function. An author, according to Foucault, is a nomination that enables categorization, which entails status distribution and inscribes meaning on texts. By this, authorship covers a historical need to explain causality with human agents and not broader, heterogeneous factors (Foucault, 1969).

The post-structuralist perspective has been accused of doing away with the acting subject, and thereby not being able to make an adequate account of how art is produced (Negus \& Pickering, 2004). However, in my opinion, the opposition between an individualistic stance and a post-structuralist stance presents an unproductive dichotomy that paraphrases the grand actor-structure debate in sociology. As an alternative, I propose posing the question of cultural production differently; asking how authoring work is carried out empirically.

Nevertheless, in the empirically founded critique, the premises of auteurism are also upheld. An example may serve as an illustration. Robert L. Carringer, an American professor of film studies, criticizes the auteurist stance for being based on empirical fallacies: "as a methodology it was untenable from the outset. Truffaut's cherished vision of the film director as Romantic artist battling alone to maintain a personal vision in an encroaching world would not hold even for his own films" (Carringer, 2001, p. 374). Pointing to the empirical inadequacy of ascribing the making of a film to one person, Carringer engages in the question of the director's primary authorship. In his detailed historical study of the making of Citizen Kane (1941), Carringer illustrates how this film is not a product of the individual artist Orson Welles, but an instance of successful collaboration. However, Carringer ends his study by quoting from the director Orson Welles: "Collaborators make contributions, but only a director can make a film" (Welles in Carringer, 1996, p. 134). Thus, Carringer's study concludes with a confirmation of Welles' auteurist claim that the director is the single element in filmmaking that is indispensable. In the same manner, Carringer proposes a methodology for collaboration analysis that consists of temporarily suspending primary authorship and then reinscribing a primary author (2001). Thus, Carringer is caught up in the question of primary authorship, which makes him insist that a collaboration analysis must hold on to a primary author, despite the empirical findings in his own study that demonstrate that agency cannot be limited to the director alone.

\section{Art as collective action}

In this article, the theoretical grounding of the analytical approach derives from the tradition of symbolic interactionism, represented by the American sociologist Howard Becker's perspective on art as collective action (Becker, 1974, 2008). Whereas previous empirical 
studies of film production have highlighted industry structures and their inherent unequal power relations (Schatz, 2004; Spadoni, 1995; Staiger, 1981, 2004), the interactionist perspective on the other hand poses it as micro-sociological, including empirical question on how collaboration proceeds.

Reversing the problem of primary authorship, Becker starts from the premise that artistic creation cannot be described in individualist terms. Rather, art is an activity that involves a large number of people. Out of these, a few are believed to be talented and gifted, consequently they are entitled artists and perform what Becker calls "core activities". The rest of those involved are named "support personnel" by Becker, as they perform assisting activities. Artists and support personnel are connected via "cooperative links", which describe the contributions others make that the artists depend on. Rather than concluding that the artist is the primary author, Becker holds that: "The artist thus works in the centre of a network of cooperating people, all of whose work is essential to the final outcome" (2008, p. 25). In other words, Becker stresses the crucial importance of all involved in the collaborative process, portraying the artist as an outcome of the network rather than its starting point. This demonstrates that cooperative links between the artist and the support personnel are necessary for the artist's work; in fact, the cooperative links constitute the center of the network that the artist embodies.

The symbolic interactionist perspective opens the way for seeing filmmaking as an ongoing collective activity. Furthering this perspective, stressing its symbolic dimension, I propose that the notion of the auteur might be influential in such ongoing collective activity as it comes to work as a principle; an organizing device. Thus, I suggest that the ideal of the director to deliver intention, origin, content, coherence, distinction, and quality of a film can be seen as a notion that may become activated during the process of collaboration, and, by this, may have consequences for the collaborative process.

\section{Two cases of debut filmmaking}

As mentioned in the introduction, two case studies of the making of Danish debut films provide the empirical material for the analysis. Both cases derive from a study about how the process of development is organized in Danish film production, which I conducted for my dissertation in 2006-2007 (Strandvad, 2008). To obtain empirical knowledge about the phase of development, I used ethnographic methods: making observations, interviewing, and reading additional case material (Ragin \& Becker, 1992). These methods were chosen because they seemed useful for studying that which I was interested in; namely, the micro processes of collaborative work. Moreover, quantitative information regarding this phenomenon is limited, i.e., most often nonexistent.

The research design of my study was to follow a number of different film projects during the process of their development. Gaining access to this type of process turned out to be rather difficult, which is similar to what other social scientists have experienced when study- 
ing on-set filmmaking by ethnographic methods (Bechky, 2006, 2007; Soila-Wadman, 2000, 2003). Hence, I spent the first half year of my research negotiating access with various producers. Eventually, in August 2006, two young producers agreed to let me study their work. Each of these producers located one project under development that I could follow. I finished my field studies in the two cases in July and August 2007. Thereby, I was in contact with both projects for approximately one year.

Originally, I had planned to study the projects by attending regularly held development meetings as a participant observer, along with conducting in-depth interviews. However, this was only possible in one of the cases. In the other case, no scheduled meetings were held and I had to adjust my research methods accordingly. Moreover, as the producers were my points of entry, they became key informants in both cases.

Project A consisted of a director, a producer, and a development producer. All three of these people were in their 20s and 30s and none of them had made a feature-length film before. The two producers had recently been hired by a well-established production company to initiate new projects; their job was to bring in talented directors and set up projects with them. Director A and the producer knew each other from film school, but had not previously collaborated. The CEO of the production company followed the project on the sideline, but did not intervene in the process, except for rare encounters, as this extract from field notes illustrates:

[Name of CEO] comes in and kisses [director A] on the cheek [...] 'I'm looking forward [...] we are so excited about this'. He turns around to leave and adds: 'Tell me if I should come in and shine over you all. Say hello to your family' (observation notes, case A, October, 2006)

Project B consisted of a director, a producer, and a scriptwriter. As in case A, all three were in their $20 \mathrm{~s}$ and $30 \mathrm{~s}$ and none of them had made a feature-length film before. All three had recently graduated from three different film schools, nationally and internationally. Moreover, this was the first fiction feature-length film produced by the production company. Previously, director B had made two short films at the production company, but with a different producer. None of the three members of the team had worked together before.

Over the year of my study, the two projects developed quite differently. Project A was in a very early stage of idea development when I started following the meetings of the project group and it was still at the point of constructing an idea a year later. No screenwriter was attached to the project, although the producers tried to bring various screenwriters on board throughout the year. The empirical material in this case consisted of observation notes from four development meetings (with the director, producer, and development producer), two interviews with the producer, two interviews with the development producer, one interview with the director, notes from phone calls and text messages with the producer, internal e-mails (including the director's brainstorms and the producer's comments), one synopsis, funding application to the Danish Film Institute (for manuscript support), and the response letter from the Danish Film Institute. 
Project B was at the stage of first draft when I came into contact with the group. During the year of my study, it went through the development and shooting of the film, and it was released in 2008. In project B, the scriptwriter, director, and producer did not schedule their meetings. Rather, they talked about the project on the phone or when they ran into each other at the production company. Accordingly, the empirical material about this case consisted of seven interviews with the producer, two interviews with the director, observation notes from a meeting with the film consultant at the Danish Film Institute, notes from phone calls to the producer, three synopses of the film, eight editions of the script, three funding applications (for manuscript support, development support, and production support), return letters from the Danish Film Institute, a promo of the film, and the final film.

\section{Positioning directors - reflecting romantic auteurism}

In project $A$, which was in the initial phase of developing an idea for the film during my study, the director was referred to as having potential by the producer. Asked to describe what this potential consisted of, the producer described the talent of director A by pointing to visual abilities, oddity, and an emotionally founded artistic personality:

\footnotetext{
I think that [director A] is extremely visual and odd in a way that I find is needed [...] [director $A]$ is probably more an artist than a craftsperson [...] I mean it is very emotional for [director A] (interview with producer A, September, 2007).
}

Later on in the same interview, the producer expanded on this: "I really think that [director A] is original [...] I mean [director A] has a kind of style, an own style, and I think it's very rare that you have that so early on in your career" (interview with producer A, September, 2007). As the producer explained it, director $A$ had a unique style, which was considered to be exceptional and valuable by the producer.

Although director A was not explicitly described as an auteur, the substance of the term was duplicated in the producer's description of the talent of director A. Director A was described as a unique talent with an unconventional and distinct visual style characterized by its weirdness, and this description reflects the aesthetic qualities attributed to auteurs since Truffaut (Caughie, 1996).

Director B was not spoken of as a talent in the same way as director A, but this did not mean that the auteur notion was not at play in this case. On the contrary, the abilities of director B formed the premise for the project. In one of the first interviews I conducted with producer $B$, the introduction I got to the film project was that: "the film is born by the director; it is director-driven so it is the director's own ideas that power the work" (interview with producer B, September, 2006). The producer explained that the director was the originator of the film, the driving force of the project, and the motive for making it. In other words, the importance of the director was unquestionable: "The entire project is that it is [director B]'s film" (interview with producer B, May, 2007). Director B shared this view: 
The type of films I make, and which [name of film consultant] supports, are director-driven; more personal and obscure - it's different if you for instance start by addressing an audience. I don't think about an audience at all, I try to keep that as far away as possible and let my thoughts run free (interview with director B, November, 2006).

In clarifying the purpose of the project, director B as well as the producer suggested that the film was meant to show the director's authorship. To give an explanation of how this authorship was obtained practically, director B explained:

I have a good sense of what I want and what I like, and that is important as a director because you are a kind of taste-machine. It is like a sieve that everything has to be poured into and those things that get through have my personal imprint (interview with director B, November, 2006).

By describing the function of the director as a tasting machine, which selects material and imprints all chosen material with a distinct mark, director B proposed that a director acquires authorship from acting as decision-maker regarding every part of the film. This approach became clear in the collaboration on the script. As the producer described it, a scriptwriter had been attached to assist the director: "[scriptwriter B] wrote onto [director B]'s idea" (interview with producer B, September, 2006). Director B confirmed this, clarifying that the scriptwriter had formulated a storyline based on their conversations (interview with director B, November, 2006). Director B had described the idea for the film and the scriptwriter had then put it on paper. "We write together", director B explained (ibid.). When asked if writing together was challenging director B stated: "it probably is for the writer. As a writer you have to put yourself into it and step back, all at the same time" (ibid.).

After the fourth edition of the script had been made, the scriptwriter was removed from the project (interview with producer, January, 2007). From the fifth to the eighth and final edition of the script, director B wrote without a scriptwriter to assist. According to director B, this was because "now it's so much in the details, it's important how it's formulated, I have to make decisions and [name of scriptwriter] cannot do that for me" (interview with director B, February, 2007). As an alternative, director B used the film consultant as an advisor on rewriting the script, along with the leading actor and an experienced Danish film director. According to director B, the experienced film director had advised him: "you have to do it yourself or sit in [while the scriptwriter writes]. [Name of experienced film director] is a tough script guy. He spent two years writing [title of film] and four-five scriptwriters, wore them down" (ibid.).

As these quotes indicate, the premise of the film was to display the authorship of the director. This raison d'être can be seen as activating the auteur notion, since positioning the director as motive power resonates with the auteurist conception of the director as the primary author (Livingston, 1997).

Both the positioning of director $A$ as a unique talent and the positioning of director $B$ as origin, motive, and decision-making-filter of the film illustrate that the auteur notion forms 
a point of reference for the two projects from their very beginning. In project A, the distinctive visual style of the director is highlighted, which resonates with the auteurist aesthetic evaluative criterion from Truffaut; that an auteur should have a recognizable cinematic style. In project $B$, on the other hand, the decisive power of the director is emphasized, which reflects the claim of the auteur as primary author; that the director is the originator of the film whose personality is accordingly visible in the film.

In that way, both projects reproduced the three assumptions of romantic auteurism; that the director is the creator of the film, the film expresses the individuality of the director, and that filmmaking that lives up to these criteria is distinguishable and desirable (Caughie, 1996). Firstly, as both projects were founded on an ambition of demonstrating the directors' authorship, the notion of the auteur was activated from the outset. Thus, the directors were positioned at the center of the projects and their abilities became the starting point and driving force. Secondly, both cases shared the auteurist assumption that the personality of the director becomes inscribed in the film. Finally, the informants in the two cases defined this kind of filmmaking as a particular type, which they characterized as directordriven. Although the informants seemed to value this type of filmmaking, especially the producers started highlighting its weaknesses later on in the process. Corresponding with their experiences, the producers' admiration for auteurism started to shatter. These problematic developments are what the next section considers.

\section{Problems of organizing for the auteur - case A}

As illustrated above, in project A, the producer considered director A to be a great talent, and this opinion formed the starting point for the process of developing a film together. When I came in contact with the project, it had been running for two months and there had been a couple of meetings. The meetings were formed as conversations, centering on director A, who was asked: "What interests you? What do you feel like?" (interview with producer A, September, 2006). As such open questions laid the ground for developing an idea for the project, the meetings involved a lot of talk about various preoccupations, interests, and thoughts of director $A$.

The first meeting I observed in project $A$ was based on ideas, which the director sent in an e-mail a few days before. These sketches consisted of thoughts about themes, locations, characters, elements, pictures, and personal experiences that could possibly be put to use in the film (mail from director A, October, 2006). At the meeting, the primary concern of the producers was to find a scriptwriter to assist director $A$ in developing a story line (observation notes, case A, October, 2006). With this aim, after the meeting, director A contacted an internationally renowned fiction writer, who nevertheless declined the offer of writing a script. The next meeting was, once again, based on sketchy writing by director $A$ (mail from director A, November, 2006). Also, once again, the meeting centered on the producers' agenda of finding a screenwriter (observation notes, case A, November, 2006). This time, the 
producers expressed optimism very explicitly, opening the meeting by declaring: "It is fabulous writing" (ibid.). An hour into the meeting, this optimism started to become combined with signs of growing impatience, such as the producer's suggestion: "Couldn't you just start?" (ibid.). Both quotes exemplify that the producer encouraged director A to get going. However, while on the one hand assuring director A that the project was on the right track, the producers on the other hand also attempted to push the director into making progress.

After this meeting, director A transformed the early writings into a synopsis that was sent to apply for funding from the Danish Film Institute. A few months later, the group received an answer that concluded: "It is, however, my judgment that, despite the long time you have spent on your preliminary work, you have not gotten very far in finding a narrative structure yet" (letter from film consultant, February, 2007). The letter from the film consultant was critical of the lacking narrative in the synopsis and did not hold much hope for the prospect of granting subsidies, but invited director $A$ to an inspirational meeting.

Because of travel, this meeting was postponed two months. In the meantime, director $A$ took the story in a new direction (observation notes, case A, March, 2007). Consequently, the idea from the synopsis had been dropped by the time the meeting was held (observation notes, case A, May, 2007). In view of that, the film consultant asked the team to send in a time plan for the next period of development of the project. However, director A did not commit to specific deadlines and decided, after a couple of weeks, to withdraw the application (phone call to producer A, June, 2007). Thus, after a one-year process of development, director $\mathrm{A}$ and the producer started up a development process of another idea.

When evaluating this course of development that concluded with a withdrawal of the funding application, the producer referred to the artistic personality of director A. In that way, the auteur notion became activated as an explanation for the outcome of the process (interview with producer A, September, 2007). According to the producer, director A's artistic personality caused several difficulties which made the process troublesome. It was difficult for director A to stick to the same idea for a longer period of time because creative inclinations changed constantly. It was difficult for director A to keep deadlines and fit into calendars and plans, because it was a very emotional thing to develop an idea. In addition, it was difficult for director $A$ to participate in only a few and formalized meetings, because the creative process thrived in sparring sessions that took longer time and demanded a more informal setting. All of these difficulties were used by the producer as explanations for why the project had not made progress in the desirable manner and pace. Thus, by seeing the director as an artist, the producer could explain the problems of the project. And not only did such references to the artistic personality provide an account of the dead-end process, it moreover legitimated it. That is, by activating the auteur notion, the producer could make allowance for the problems as they came to be seen as caused by the very reason for making the project; the director's auteurist abilities.

Ironically, director A did not experience having the difficulties that the producer reported about (interview with director A, February, 2007). On the contrary, director A 
explained about an eagerness to engage in an idea for a longer period of time, expressed a wish for deadlines, and found that formal meetings were convenient as they represented seriousness. Rather than speaking of difficulties when accounting for switching ideas, director A casually declared: "But now I don't even know if that is the story I want to do any more [laughs]" (observation notes, case A, June, 2007). Whereas the producer justified the withdrawal of the application by pointing to problems caused by the director's artistic personality, director A explained the same occurrence by a change of interest. By this, director A did what the producer initially asked for, which was to figure out what you are interested in and feel like doing.

So, while the producer pointed to artistically founded difficulties of the director when accounting for the unplanned development of the project, the director spoke of searching for what one would like to do. Both of these explanations activated the auteur notion. But whereas the producer described a negative version of the artistic personality's possible disadvantages, which can be drawbacks in the development process, the director gave a positive account of living up to the expectations of being an artist, which nevertheless may lead to not being able to choose an idea.

By drawing attention to the actions of the producer and the director, it can be seen that the position of director A was constantly supported. That is, director A was persistently positioned as an artist, who has to look inside to pick an idea. And this positioning was not least initiated by the producer. In other words, the director's artistic personality, which the producer complained came to cause various problems in the process, was supported by the producer's own actions. As the project was based on the talent and inclinations of the director, these were continuously confirmed as foundational and came to be indispensable. Consequently, the project was organized around the expectations of director A's abilities. In that sense, the project was ruled by the auteur notion, and not only in a beneficial way. Thus, the explanation for the withdrawal of the funding application may not be the artistic personality of director $\mathrm{A}$, but that the presumptions of this personality became a hindrance for the project.

\section{Problems of organizing for the auteur - case B}

In contrast to project $A$, project $B$ managed to progress to receive funding for making the film. When the shooting of the film was about to begin, however, director $B$ became anxious. The producer explained: "[director B] is completely, extremely nervous. [Director B] says 'I cannot sleep and we don't begin for two weeks, what if I don't sleep for two weeks?'” (interview with producer B, March, 2007). As the producer explained it, director B was worried about not being able to make the film. The producer assisted director $B$ in handling these doubts by repeating advice that was given by the film consultant about "embracing uncertainty and using it" (ibid.). To embrace uncertainty was a maxim that the film consultant had launched to assure the team that it is possible to put insecurity to good use. The 
producer and the director took on this approach and viewed it as a positive thing, i.e., being open to the material.

However, halfway into the shooting of the film, director B became ill. The diagnosis that director B was given was stress; its symptoms were sleeplessness, anxiety attacks, and crying.

Although director B pleaded to halt the project, the producer decided to continue after consulting with the film consultant and the head of the production company. According to the producer, both of them reacted calmly and firmly when receiving the news about the director. For instance, the head of the company responded: "Oh, well [...] It could as well have been that the set had burned down" (interview with producer B, May, 2007). Instead of expressing panic, both of them advised the producer to tackle the problem and move on. The rest of the team responded in much the same manner when the producer reported the situation to them, as most of them had experienced more problematic film projects. This made the producer conclude that the state of the director could have been worse: "[director B] doesn't tyrannise, doesn't call in the middle of the night and terrorise others" (ibid.). After all, director B was in a condition that did not harm anyone else.

So, the team continued making the film, although director B was more or less incapable of directing. The producer explained: "there are some shots which [director B] does not take part in, where [director B] is just lying down next door, staring into space" (ibid.). In that way, the team shot some of the scenes without the director being present. Other scenes director B was attending but rushing through. The producer explained: "Normally, it is the director that wants to retake things, but in this case it is the photographer that wants to repeat scenes" (interview with producer B, June, 2007). Hurrying to finish, director B was content with the first result that came along. In addition, director B proposed cutting out scenes to speed up the process and close earlier. As the producer described it, this appeal created a difficult situation:

Last Sunday [director B] had a total collapse. [Director B] called and was very upset, spoke incoherently and suggested to remove twenty scenes and finish the film in four days [...] [Director B] kept repeating 'I can't stand it anymore'. [Director B] wanted a plan that allows for new breakdowns, but I said that we cannot make a plan with holes in it [...] and I said that we do not cut out twenty scenes. But I was out of my mind on Sunday, because what would happen if [director B] cracks? Do we then need to employ another director or are we to finish it without a director? (interview with producer B, May, 2007).

Although the producer decided to ignore the protests of director $B$ and continue the project, this was not an easy decision, because it questioned the participation of the director. However, the photographer and the editor agreed with the producer on finishing the film if director B proved unable to do so. When the producer informed director B about this decision, it relieved the situation on the set. The editor started to ask aloud jokingly: "When are we to direct? If I'm going to make it, it has to be this way" (ibid.). This questioning of the artistic leadership got director B going, replying to the editor: "no, it has to be like this" 
(ibid.). Yet, although director B came to participate, performing the job of directing, this exchange of words also illustrates that when the director lost grip of the project, other members of the project team started to take over the job of directing. By this, the position of the director was challenged, as the producer explained: "I begin to doubt whether [director $B]$ is a real film director" (ibid.). When director B turned out to be incapable of performing the task of directing and leading, the team took the project in hand and made director B's film. This created a paradoxical situation because the raison d'être of the project was to make a film authored by director $B$, but it was made by others.

At first glance, this situation clashes with the assumption that the director has primary authorship of the film. Thus, it seems that the auteurist expectation of the director as indispensable would be rejected when the director did not attend to the making of the film. However, although director B's stress symptoms posed a problem and made the position of the director questionable, the producer turned it into an occurrence that had a positive influence and thereby confirmed the director's authority over the project. When viewing the early results together with the photographer and the editor, the producer discovered that director B's shaky condition had become a source for the film: "Of course it's unpleasant, but maybe it is not so bad. It has some human consequences, but it is good for the result" (ibid.). According to the producer, the state of director B caused a distinct character in the resulting film, which was positive. To see the director's troubles as beneficial for the project not only made these problems bearable, it furthermore confirmed the auteur notion upon which the project was founded.

As this sense-making of the director's illness demonstrates, the members of the project team sustained the auteur notion despite its unsteadiness. Even when the authorship of director B was actually breaking down and the central position of the director could have been overthrown, this position was reinstated and the durability of the auteur notion thereby reinforced. Despite the fact that others carried through with the project, and the abilities of director B were questioned, the belief in the director's authorship was not dissolved. In other words, the absence of director B did not lead to dissolution of the director's central position in the collaboration. Thus, the auteur notion was upheld regardless of its indefensibility; the core function of the director was maintained regardless of the contributions made by director $B$ in the unfolding collaboration.

\section{Discussion of auteurism versus triadic collaboration}

As the analysis illustrates, the notion of the auteur was invoked in the two cases even though directors $A$ and $B$ were debutantes. Activating the auteur notion provided, first of all, a rationale for making the films. Moreover, positioning the directors in a way that reflects romantic auteurism constituted a guideline for organizing the projects. Yet, the analysis furthermore demonstrates how the ideal of the auteur was disrupted in the two cases when both directors turned out to be unable to meet the auteurist expectations of 
delivering authorship over the projects. However, these failures did not lead to a rejection of the auteur notion. Rather, the auteur ideal was maintained despite its downsides and dysfunctions. Why is this so?

One explanation would be that these cases are exceptional. According to the producer in case A, this project was an atypical example: "the meetings are very submissive, other meetings are more like 'if there's no development we stop', it's actually a little unusual" (phone call to producer A, June, 2007). As the quote demonstrates, the producer considered the long development process in case $A$ to be unusual. In case $A$, the producer invested more time and was more tolerant and patient with the director than usual.

Following from this, another explanation for the maintenance of the auteur notion would be that the producers in the two cases were too weak; that they were subordinate to the directors. To a large extent, the producers' reluctance to interfere with the visions of the directors can be seen as resulting from the role that was played by the primary funding agency; i.e., the film consultant. In their attempts to manage the directors, the producers in both cases relied on the intervention of the film consultant. In case A, the producer explained:

[development producer] and I had the impression that no matter how much we tried to add a story, [director A] backed off. Every time we started talking about an actual plot. We tried scriptwriters, and now the strategy to send it in [to the Danish Film Institute]. It's also in that way you can use [name of film consultant] as an active player (phone call to producer A, February, 2007).

In case B, the producer elaborated on this explanation of using the film consultant as an active player in the process with the director:

[Name of film consultant] plays a very active role and has a say. But it's not a power struggle. Many people get extremely annoyed, but we see it as an expanded film school. If [name of film consultant] was stupid it would be annoying, but [name of film consultant] is not (interview with producer B, November, 2006).

As producer B explained it, the film consultant was brought in as a participant in the process. Since the film consultant had great expertise, and controlled a large portion of the money for the film, the filmmakers willingly followed the advice they were given (see also Author, 2009). In a later interview, producer B added: "Maybe I give [name of film consultant] too much power, but [name of film consultant] is good to lean on" (interview with producer B, May, 2007). However, by relying on the film consultant to engage in the process, the producers simultaneously downplayed their own role. Furthermore, the film consultant was primarily interested in the process of developing the skills of the directors. As director B put it: "[name of film consultant] is 100\% the director's man" (interview with director B, November, 2006). In that way, the film consultant came to support the central role of the directors and consequently the importance of the producers shrank. 
The actions of the film consultant demonstrate ambivalence towards the notion of the auteur, which can be found in Danish film in general. In Denmark, the auteur tradition was dominant until the National Film School of Denmark initiated a triadic collaboration model in the early 1990s (Bjerre \& Nesgaard, 2003; Wiedemann, 2005). The school introduced the triad of director, producer, and screenwriter to oppose the auteur tradition, which was seen as being unproductive because of its dependence on the director alone, causing conflicts between the director and the other contributors. Yet, the auteur tradition persists although it is no longer seen as the only formula for filmmaking. As Ole John, head of the producer program at the National Film School of Denmark from 1991 to 2008, puts it: "We are after all still director-governed and we of course have to be that in Danish and European [cinema], it is our tradition that naturally the director is the most important person" (interview with Ole John, October, 2006).

Perhaps this phenomenon is not restricted to a Danish context. In an ethnographic study of the training at Grad Film in New York City in 1985-86, Lisa Henderson shows how auteurism governed the practices of teachers and students: "in the school, filmmaking is the work of artists, not deal makers, corporate functionaries, or the technicians of commercial formulas" (Henderson, 1995, p. 152). According to Henderson, the underlining notion of the auteur was what defined the program at Grad film. Both teachers and students strived to implement and maintain the idea of the writer-director whose personality is defining and traceable. Not only did film become art by following this tradition. Moreover, it provided the school with a way of operating.

Henderson suggests that auteurism "resolves certain crises of attribution by promoting a way in which films may be traced back to a singular artistic source, which has been useful for critics and distributors" (ibid, p. 162). For filmmakers, this means that individual artistic intention and control becomes a gold standard. Thus, authorship may be seen in a positive light as a technique of the self (Staiger, 2003, p. 49fff). Or this optimistic view may be altered if we remind ourselves of Foucault's diagnosis of how the inner self is constructed in confessional practices (Foucault, 1998), and what implications self-government has for the shaping of the individual (Foucault, 1991; see also Rose, 1999).

\section{Conclusion}

Based on a dual case-study of the making of two Danish debut films, the analysis in this article has exemplified how the notion of the auteur is transferred from film theory to filmmaking practices. Traces of auteurism are identified in both cases as the abilities of the directors are seen as the starting point and motive for making the films. In that sense, from the outset, the processes become organized for the auteur.

In case A, during the early development phase, the producer invokes the auteur notion by regarding the director as a great talent. When it turns out to be difficult for the director to meet these expectations, the producer makes allowance for the difficulties by explaining 
them away as caused by an artistic personality. Thus, the producer maintains the notion of the auteur as the governing idea of the project, despite its consequences. This creates a situation that hinders rather than helps the director; the activation of the auteur notion comes to be a heavy burden that the director can neither lift nor get rid of.

In case B, which is observed during the shooting of the film, the auteur notion is challenged fundamentally as it turns out to be doubtful whether the director is able to perform the task of executing the project. As the director cracks, the team undertakes the job of making the film while the director stands on the sidelines. Consequently, this might imply that the auteur notion would be rejected and substituted. However, the absence of the director does not lead to dissolution of the director's central position in the collaboration. Despite the fact that others carry through the project and the authorship of the director is questioned accordingly, the auteur notion is upheld as the basic logic of the project.

Bringing the notion of the auteur into play transforms the collaboration from potentially being a unification of a number of collaborators' work to isolating the director as the most central agent in the project, which has critical implications for the collaboration. In the two cases, this personification of the project becomes a problem for the directors; to carry the project causes insecurity and anxiety. For the collaborators the activation of the auteur notion becomes a balancing act of, on the one hand, contributing to the project while, on the other hand, supporting the central position of the director. It follows from this that the auteur notion can be seen as changing the interaction in the collaborative process into something that could have been different if this notion had not been brought into play. Accordingly, the article suggests that if the auteur notion had not been activated in the two cases, the problems of the directors might not have occurred, or they might not have been as dominant.

\section{References:}

Andrew, D. (1993). The Unauthorized Auteur Today. In Collins, J., Radner, H. \& Collins, A.P. (eds.), Film Theory Goes to the Movies. New York/London: Routledge, pp. 77-85.

Barthes, R. (1990). The Death of the Author. In Image, Music, Text. London: Fontana Press, pp. 142-148.

(Originally published 1968).

Bechky, B. (2006). Gaffers, Gofers and Grips: Role-Based Coordination in Temporary Organizations. Organization Science, 17 (1), 3-21.

Bechky, B. (2007). Personal communication (e-mail sent via Carsten Østerlund).

Becker, H.S. (1974). Art As Collective Action. American Sociological Review 39 (6), 767-776.

Becker, H.S. (2008). Art Worlds. 25 th Anniversary Edition. Updated and Expanded. Berkeley: University of California Press. (Originally published 1982).

Becker, H.S., Faulkner, R.R. \& Kirshenblatt-Gimblett, B. (eds.) (2006). Art from Start to Finish: Jazz, Painting, Writing, and Other Improvisations. Chicago: The University of Chicago Press.

Bjerre, C. \& Nesgaard, P. (eds.) (2003). Den Danske Filmskole. The National Film School of Denmark. Studieordning [Study programme]. Copenhagen: Den Danske Filmskole.

Bordwell, D. \& Thompson, K. (1993). Film Art: An Introduction, $4^{\text {th }}$ edition. New York: McGraw-Hill. 
Burke, S. (1998). The Death and Return of the Author: Criticism and Subjectivity in Barthes, Foucault and Derrida. Edinburgh: Second Edition, Edinburgh University Press. (Originally published 1992).

Carringer, R.L. (1996). The Making of Citizen Kane, Revised and Updated Edition. Berkeley: University of California Press.

Carringer, R.L. (2001). Collaboration and Concepts of Authorship. PMLA 16 (2), 370-379.

Caughie, J. (ed.) (1996). Theories of Authorship. London, New York: Routledge \& Kegan Paul Ltd. (Originally published 1981).

Corrigan, T. (1991). The Commerce of Auteurism. In A Cinema Without Walls. New Brunswick: Rutgers University Press, pp. 101-136.

Foucault, M. (1979). What is An Author? In Harari, J.V. (ed.), Textual Strategies: Perspectives in Post-Structuralist Criticism. Ithaca: Cornell University Press, pp. 141-160. (Originally published 1969).

Foucault, M. (1991). Governmentality. In Burchell, G., Gordon, C. \& Miller, P. (eds.), The Foucault Effect Studies in Governmentality. Chicago: The University of Chicago Press. (Originally published 1978).

Foucault, M. (1998). The History of Sexuality Vol. 1: The Will to Knowledge. London: Penguin Press. (Originally published 1976).

Gaut, B. (1997). Film Authorship and Collaboration. In Allen, R. \& Smith, M. (eds.), Film Theory and Philosophy. Oxford/New York: Oxford University Press, pp. 149-172.

Gerstner, D. \& Staiger, J. (eds.) (2003). Authorship and Film. New York: Routledge.

Giddens, A. (1984). The Constitution of Society: Outline of the Theory of Structuration. Cambridge: Polity.

Grodal, T., Larsen, B. \& Laursen, I.T. (eds.) (2005). Visual Authorship: Creativity and Intentionality in Media. Northern Lights, Film and Media Studies Yearbook 2004. Copenhagen: Museum Tusculanum Press.

Henderson, L. (1995). Directional Intention and Persona in Film School. In Gross, L. (ed.), On the Margins of Art Worlds. Boulder: Westview Press, pp. 149-166.

Livingston, P. (1997). Cinematic Authorship. In Allen, R. \& Smith, M. (eds.), Film Theory and Philosophy. Oxford/New York: Oxford University Press, pp. 132-148.

Lovell, A. \& Sergi, G. (2005). Making Films in Contemporary Hollywood. Oxford: Oxford University Press.

Martin, A. (2004). Possessory Credit. Framework 45 (1), 95-99.

Negus, K. \& Pickering, M. (2004). Creativity, Communication and Cultural Value. London: Sage.

Orgeron, D. (2007). Authorship Comes of Age in the Cinema of Wes Anderson. Cinema Journal 46 (2), 40-65.

Ragin, C.C. \& Becker, H.S. (eds.) (1992). What is a case? Exploring the foundations of social inquiry. Cambridge: Cambridge University Press.

Rose, N. (1999). Governing the Soul - The Shaping of the Private Self, 2nd ed. London and New York: Free Association Books. (Originally published 1989).

Schatz, T. (2004). The Whole Equation of Pictures from The Genius of the System. In Braudy, L. \& Cohen, M. (eds.), Film Theory and Criticism, Sixth Edition. New York/Oxford: Oxford University Press, pp. 652-6. (Originally published 1988).

Sellors, P. (2007). Collective Authorship in Film. The Journal of Aesthetics and Art Criticism 65 (3), $263-271$.

Soila-Wadman, M. (2000). Getting in touch with what's going on in a film project - some considerations on epistemology and method. Paper presented on Organizing Aesthetics, EISAM, 12-14 May, Certosa di Pontignano, University of Siena, Italy.

Soila-Wadman, M. (2003). Kapitulationens estetik: Organisering och ledarskap i filmprojekt. Doctoral thesis. Stockholm: School of Business Research. Fields of Flow.

Spadoni, R. (1995). Geniuses of the systems: Authorship and evidence in classical Hollywood cinema. Film History 7, 362-85. 
Staiger, J. (1981). The Hollywood mode of production: the construction of divided labor in the film industry. PhD-thesis, University of Wisconsin-Madison: UMI.

Staiger, J. (2003). Authorship approaches. In Gerstner, D. \& Staiger, J. (eds.), Authorship and Film. New York: Routledge, pp. 27-60.

Staiger, J. (2004). Part Two: The Hollywood mode of production to 1930 \& Part Five: The Hollywood mode of production, 1930-60. In Bordwell, D., Staiger, J. \& Thompson, K., The Classical Hollywood Cinema: Film Style er Mode of Production to 1960. London and New York: Routledge, pp. 85-154 \& 309-38. (Originally published 1985).

Strandvad, S.M. (2008). Inspirations for a new sociology of art: A sociomaterial study of development processes in the Danish film industry. PhD-thesis, Doctoral School of Organization and Management Studies, CBS/Copenhagen Business School. PhD Series 10. 2009.

Strandvad, S.M. (2009). New Danish Screen - an organizational facilitation of creative initiatives: gatekeeping and beyond. International Journal of Cultural Policy 15 (1), 107-121.

Wexman, V.W. (ed.) (2003). Film and Authorship. New Brunswick, New Jersey, and London: Rutgers University Press.

Wiedemann, V. (2005). Immaculate Conception: Scriptwriting at the National Film School of Denmark. FILM 41 (February), 24-26.

Sara Malou Strandvad

Assistant Professor, PhD

Department of Communication, Business and Information Technologies

Roskilde University, Denmark

malou@ruc.dk 